\title{
Development Of Quality Measurement Of Cooperative Governance Implementation
}

\author{
Devid Putra Arda ${ }^{*}$, Etty Murwaningsari² ${ }^{2}$ Juniati Gunawan ${ }^{3}$ \\ ${ }^{1}$ Mahasiswa Doktoral, Universitas Trisakti \\ 2,3 Universitas Trisakti \\ *Corresponding Author: \\ Email : devidardazhaqy@gmail.com
}

\begin{abstract}
.
According to the Constitution of the Republic of Indonesia, Article 33 of the 1945 Constitution, the basis for the establishment of cooperatives in Indonesia, is intended to be one of the solid pillars of the nation's economy. Cooperatives have not played much role in reducing people's poverty and realizing food independence (Tjakrawerdjaja, 2019). The purpose of this study is to develop a measurement of the quality of the implementation of cooperative governance. Cooperative governance that is not based on the principle of good cooperative governance has the potential to have a negative impact on the health of cooperatives and the survival of cooperatives (Budiyono \& Susilowati, 2017). The research method used in this study is qualitative research, which emphasizes analyzing and interpreting a problem (Afrizal, 2014). Participants in this study are those who have knowledge and experience about cooperatives. The population will spread across the scope of the cooperative, especially at the level of administrators, supervisors, and management. The process of analyzing research data is carried out inductively, namely data analysis is carried out simultaneously with data collection in a cyclical process (Nugrahani, 2014). The data analysis model that the author uses is the interactive analysis of Miles \& Huberman. In order to collect data from information sources or informants, researchers need assistance instruments that are used semi-structured interview guidelines. The next stage of this research is to conduct content analysis. The main purpose of content analysis is to support answers to research questions, namely the extent to which cooperative governance is implemented. Content analysis is carried out on the Accountability Report of the Cooperative Management and Supervisory Board. The results of this study indicate that the Development of Quality Measurement of Cooperative Governance Implementation, produces 15 (fifteen) dimensions and 97 (ninety-seven) indicators. The level of implementation of the development of measurement of the quality of the implementation of cooperative governance in the two samples of cooperatives obtained the findings: (a) BPK RI Cooperatives received the predicate "not good"; (b) KSP SMS implementation level gets the predicate "Good".
\end{abstract}

Keywords: Cooperative, Good Cooperative Governance, The Implemention of GcoG

\section{INTRODUCTION}

According to the Constitution of the Republic of Indonesia, Article 33 of the 1945 Constitution, the basis for the establishment of cooperatives in Indonesia, is intended to be one of the solid pillars of the nation's economy. The degree of cooperatives is very noble in the Indonesian economic system. Its existence is confirmed in Article 33 of the 1945 Constitution, and stated in Article 4 of Law Number 25 of 1992 concerning Cooperatives. The explanation of Article 33 of the 1945 Constitution clearly states that cooperatives are a form of entity in accordance with the Indonesian economic system - the Pancasila economic system. Strengthened by the statement in Article 4 of Law Number 25 of 1992, cooperatives function to realize and develop the economy as a joint effort based on the principles of kinship and economic democracy.At the age of more than 70 years, cooperatives have not played much role in reducing people's poverty and realizing food independence (Tjakrawerdjaja, 2019). The economic gap is still concerning, with a Gini ratio of 0.41 in 2016, and only moved down slightly at 0.393 in 2017 and 0.384 in 2018 (BPS, 2018). Plus the misery of the people is even more tragic 
when it is highlighted from the land tenure of 0.64. According to Central Bureau of Statistics (BPS), this percentage is categorized as very unequal. Likewise, the wealth of four of Indonesia's richest people is equivalent to a combined 100 million poor people in Indonesia (Tjakrawerdaja, 2019). The success of cooperatives in achieving success, and the failure of cooperatives to maintain their existence, depends on the ability of cooperatives to carry out good and consistent governance. It is realized that the implementation of governance in cooperatives is much more complicated and complex than the implementation in companies. Because at the management level it has an opportunistic character and most cooperatives do not have a comparative advantage (Miguel \& Santamaria, 2017). The available governance is prepared by the regulator, namely the Ministry of Cooperatives and SMEs of the Republic of Indonesia, which has not specifically developed cooperative governance. It is only reflected in a number of Ministerial Regulations or Deputy Ministerial Regulations.

Deputy Regulation for Institutional Sector of the Ministry of Cooperatives and Small and Medium Enterprises Number 04/Per/Dep.1/III/2018 concerning Cooperative Rating Criteria and Indicators Kretaria and Cooperative Rating Assessment Indicators. This Deputy Ministerial Regulations (Perdep) does not yet fully discuss cooperative governance. Does not include compliance with tax laws and current accounting regulations, including compliance with the preparation of financial statements based on Financial Accounting Standards for Entities Without Public Accountability (SAK ETAP). References for cooperative governance compiled by a number of academics and practitioners are limited to the arrangement of governance for Savings and Loans Cooperatives (KSP) and Savings and Loans Cooperatives Unit (USP). The regulation only compiles the governance of savings and loan cooperatives and savings and loan cooperative units (Wibowo and Subagyo, 2017).Lack of care in the implementation of governance affects all types of cooperatives. conducting research on credit unions (credit unions) in Brazia concluded that the application of good governance will substantially improve the operational efficiency of cooperatives institutionally (Favalli, 2020). Violations of cooperative governance principles, which are dominant are transparency and accountability (Susianto \& Suyatno, 2017). This conclusion was obtained based on the results of a study of 164 cooperatives in Sukabumi, West Java. Weaknesses in the application of governance were also stated by (Sun., et al, 2019) the low quality of cooperative human resource education, as the main obstacle to implementing cooperative governance. Especially for studies on the Development of Quality Measurement for the Implementation of Cooperative Governance, there is still not much done. In particular, the measurement of a fairly complete and weighty index has been produced by the Indonesian National Police, under the name "Index of Governance of the Indonesian National Police". The preparation of this index is the result of collaboration between the Indonesian National Police and the Australian Government, the Department of Foreign Affairs and Trade, which was published in 2015. On the other hand, the preparation of a special index for cooperative governance has not been widely carried out. Among the few studies on cooperative governance, he has been conducted (Nkuranga, 2013) as Program Coordinator of Enabling Market Integration through Rural Group Enpowerment (EMIRGE) - Rwanda, with guidance from the United States Agency for International Development (USAID).

The results of the preparation of the index are called the Cooperative Performance Index (CPI) in Rwanda. However, in compiling the index, Nkuranga only focused on five dimensions, namely: (1) the legal status of the cooperative, (2) Production and quality of inputs, (3) Membership, (4) Retention strategy, (5) Linkages and relationships with the market. Another researcher, Kelvin (2018), compiled an index of cooperative supervision compliance. In his research, Kelvin describes five dimensions, namely: (1) cooperative principles, (2) institutions, (3) business, (4) finance, (5) cooperative transactions. For the context of Indonesia, the preparation of the Development of Quality Measurement for the Implementation of Cooperative Governance has not been widely discussed in a comprehensive manner.In terms of regulations, cooperative governance has not been formulated specifically and in detail. Governance is only contained in a few regulations. Among these regulations: (1) Regulation of the Deputy for Institutional Affairs of the Ministry of Cooperatives and SMEs RI 
Number 04/Per/Dep.1/III/2018 concerning Guidelines for Rating Cooperatives, (2) Regulation of the Deputy for Supervision of the Ministry of Cooperatives and SMEs RI Number 06/Per /Dep.6/IV/2016 concerning Guidelines for Health Assessment of Savings and Loan Cooperatives and Cooperative Savings and Loans Units. The published regulations do not concretely and in detail mention cooperative governance. The regulatory focus seems to be on the regulation of savings and loan cooperatives and savings and loan units. That is, it does not touch all types of cooperatives. The fact that the author describes, has not found much research on governance, especially cooperative governance. Including the Development of Quality Measurement of Cooperative Governance Implementation is still limited to being discussed by researchers, both at the international level and at the national level. In terms of regulation, there are no detailed rules and guidelines for cooperative governance that can be applied to all types of cooperatives. So regulators as well as practitioners are trying hard to direct attention to developing good cooperative governance. More specifically, it resulted in the Development of a universal Cooperative Governance Implementation Quality Measurement.

Based on the considerations described by the author, it is necessary to develop a more complete measurement of the quality of the implementation of cooperative governance, and to examine the level of implementation in Indonesian cooperatives. Cooperatives are interesting to study because, firstly, they have received prominent attention in recent years as a strategic element for achieving sustainable economic development and greater social cohesion in the context of neoliberal globalization (Bretos \& Marcuello, 2016). Second, in the context of Indonesia, cooperatives are able to save the nation's economy from the crisis. It was proven in 1998, when the economic crisis hit Indonesia, only cooperatives were able to survive because of the trust of the community. At that time, (the economic crisis in 1998), many banks rejected public savings and loans, so they turned to cooperatives in droves. (Puspayoga, 2018). Third, cooperatives can be a panacea to solve the problem of the widening economic gap between the poor and the rich. Cooperatives oppose all understandings of individualism and capitalism (Sinuraya, 2012). However, in the Indonesian context, cooperatives did not run as expected. In fact, cooperatives are like a lot of people growing on a rock, they don't want to live, they don't want to die.It can be emphasized that cooperative research is interesting to do because of its "superior" position in the Pancasila economic system but its performance has not been maximized as a driver of the nation's economy. In contrast to cooperatives in other parts of the world, the cooperatives are growing rapidly. Reporting from ICA, it collects the 5 largest cooperatives in the world, namely: (1) Groupe Credit Agricole The Groupe Credit Agricole cooperative in France has more than 10 million members in 2018. The cooperative, which was founded on November 5, 1984, has a turnover of more than USD 96.25 billion or around Rp1.42 quadrillion; (2) Groupe BPCE Founded in 2009, the Groupe BPCE cooperative has more than 35 million members in 2016. This cooperative from France is known to have a turnover of up to USD 59.03 billion or around Rp. 872.3 trillion; (3) Rewe Group Originating from Colone, Germany, the REWE Group cooperative was founded in 1927. Today, this cooperative operating in 20 European countries has a turnover of up to USD 55.85 billion or around Rp. 825.3 trillion; (4) BVR Founded in 1972, the BVR cooperative has more than 18 million people.

Now, this German cooperative has a turnover of up to USD 55.29 billion or around Rp. 817 trillion; (5) Zenkyoren The Japanese agriculture-based cooperative, Zenkyoren, has now more than 10 million members. Founded in 1951, the cooperative which also has the name 'JA Kyosai' has a turnover of up to USD 51.69 billion or around Rp. 763.8 trillion (Akurat.co). Even foreign cooperative brands are able to beat even big companies. Cooperative brands that are well known throughout the world, including: Campina ice cream, Sunkist packaged drinks, Barcelona-Spain football club, Ace Hardware Corp. (Brilio.net, 2018). Judging by this fact, it means that there is something wrong in the management of most of the Indonesian Cooperatives. The research location is focused on DKI Jakarta Province. The reason is that the population of cooperatives in this province is large. Second, the types of cooperatives in DKI Jakarta are heterogeneous. This study took the object of research in the Indonesian Supreme Audit Agency Cooperative (BPK RI) and the Setia Multi Sarana Savings and Loans 
Cooperative (KSP). The reasons for selecting the object of research are: (1) The BPK RI Cooperative has a special value, because it is under the auspices of a high state institution (BPK RI) with the main authority of BPK RI to examine the management of state finances. It can be ascertained that the management of BPK RI cooperatives, who are employees of BPK RI, are very aware of the importance of implementing good governance; (2) KSP Setia Multi Sarana is a representation of the Savings and Loans Cooperative (KSP). Various cases happened to KSP, starting from failure to pay member deposits and cases of mega corruption. Regulators also pay special attention to KSP. Marked by the enactment of the Deputy Regulation (Perdep) for Supervision of the Ministry of Cooperatives and Small and Medium Enterprises of the Republic of Indonesia Number 06/Per/Dep.6/IV/2016 concerning Guidelines for Health Assessment of KSP and USP of Cooperatives.This study tries to develop a measurement of the quality of the implementation of cooperative governance. A solution to provide awareness to cooperative stakeholders about the importance of governance for achieving cooperative performance targets for the welfare of members and society in general. Cooperative governance that is not based on the principle of good cooperative governance has the potential to have a negative impact on the health of cooperatives and the survival of cooperatives (Budiyono \& Susilowati, 2017). In terms of quality, not many cooperatives are able to achieve success in enforcing the pillars of good governance. From the problems described in the background of the problem, the objectives of the research can be described: (1) To develop a measurement of the quality of the implementation of cooperative governance; (2) Analyzing the level of implementation of the quality measurement of the implementation of cooperative governance.

\section{METHODS}

The population in this study which is based on qualitative, is more accurately called the research subject or unit of analysis. Cooperatives that are used as units of analysis are: (1) Cooperatives that have savings and loan units; (2) Savings and loan cooperatives that stand alone without having other business units. General cooperatives (non-savings and loans) selected for analysis are unique and interesting to study. For example, cooperatives owned by state agencies in charge of auditing the performance and governance of state institutions. So the authors set the BPK RI cooperative as the selected cooperative for analysis. The second cooperative that is taken as a sample is the Savings and Loans Cooperative. The author is interested in choosing one of the KSP, because of the many problems that surround the KSP, ranging from failing to pay members' deposits, to megacorruption cases involving its management.

The data collection techniques used by the researchers: (1) Prepare a list of questions to be distributed to informants; (2) In-depth interviews are guided by the list of interviews (questionnaires) that the author has developed. In-depth interview, is an open question. In-depth interviews are needed to sharpen the short "yes" or "no" answers on the questionnaire; (3) Conducting Focus Group Discussions (Focused Group Discussions); (4) Observation of the observation technique in the study is intended to explain and clarify the information obtained from the questionnaire with the actual facts in the field.The next stage of this research is to conduct content analysis. Content analysis is a method of coding manuscripts into several categories with specific criteria (Crowther \& Lauesen, 2017). The main purpose of content analysis is to support answers to research questions, namely the extent to which cooperative governance is implemented.

\section{DISCUSSION}

The development of Quality Measurement of Cooperative Governance Implementation for this research, is the Deputy Regulation (Perdep) of the Ministry of Cooperatives and SMEs RI Number: 04/Per/Dep.1/III/2018 concerning Criteria and Indicators for Rating Rating Cooperatives cannot accommodate the development of comprehensive governance. The summary of the literature review and legal documents published by the Ministry of Cooperatives and SMEs, is still not complete to design an ideal cooperative governance building. Researchers complete it with dimensions and indicators that are relevant to cooperative governance. The 
researcher adds two variables as novelty elements, namely: (1) Cooperative compliance with cooperative laws and regulations. (2) Cooperative compliance with accounting and taxation laws and regulations.

In the next stage, a comprehensive Cooperative Governance Implementation Quality Measurement Development was developed. The results of the study of Perdep No. 06/Per/Dep.6/IV/2016 and Perdep No. 04/Per/Dep.1/III/2018, as well as the addition of an index of FGD results, literature review, and interviews with related parties. In the end the author was able to develop 15 dimensions and 97 indicators for the Development of Quality Measurement of Cooperative Governance Implementation, namely: (1) Transparency, (2) Responsibility, (3) Professionalism, (4) Fairness, (5) Accountability, (6) Institutional, (7) Capital, (8) Earning Assets Quality, (9) Liquidity, (10) Independence and Growth, (11) Cooperative Identity, (12) Cooperative Compliance with Related Regulations, (13) Cooperative Compliance with Indonesian Financial Accounting Standards And Regulation of the Minister of Cooperatives, (14) Benefits of Cooperatives for Members, and (15) Benefits of Cooperatives to Society. In detail the dimensions and indicators of the Development of Quality Measurement for the Implementation of Cooperative Governance that the authors have compiled, are shown in the following table:

Table 1. Development of Comprehensive Cooperative Governance Implementation Quality Measurement

\begin{tabular}{|c|c|c|}
\hline No. & Dimensions/Indicators & Code \\
\hline I. & Dimensions: Transparency & \\
\hline 1. & There are complete and detailed financial reports presented on time & TRA-FGD-01 \\
\hline 2. & $\begin{array}{l}\text { There is a management performance report that is submitted regularly to the } \\
\text { supervisor }\end{array}$ & TRA-FGD-02 \\
\hline 3. & There are facilities/media for disseminating information in this cooperative & TRA-FGD-03 \\
\hline 4. & There is an application of cooperative digitization & TRA-FGD-04 \\
\hline II. & Dimensions : Responsibility & \\
\hline 5. & Important decision mechanisms must be taken in the RAT forum & RES-FGD-01 \\
\hline 6. & $\begin{array}{l}\text { The management is responsible for non-performing loans and tries to keep bad loans } \\
\text { to a minimum }\end{array}$ & RES-FGD-02 \\
\hline 7. & Cooperatives must keep important documents for at least 5 years. & RES-FGD-03 \\
\hline 8. & $\begin{array}{l}\text { Supervisors respond, analyze, and evaluate performance reports, work plans, and } \\
\text { RAPBK in writing, no later than before the RAT is conducted. }\end{array}$ & RES-FGD-04 \\
\hline III. & Dimensions: Professional & \\
\hline 9. & $\begin{array}{l}\text { Cooperative operational decisions are made independently (confirmation to } \\
\text { management and supervisors). }\end{array}$ & PRO-FGD-01 \\
\hline 10. & There is a separation of USP and NonUSP management. & PRO-FGD-02 \\
\hline 11. & Separate presentation of USP financial statements from NonUSP units. & PRO-FGD-03 \\
\hline 12. & There is a cooperative code of conduct. & PRO-FGD-04 \\
\hline 13. & $\begin{array}{l}\text { There is an integrity pact for the management and supervisors including being free } \\
\text { from conflicts of interest. }\end{array}$ & PRO-FGD-05 \\
\hline 14. & There is a proper remuneration system for management level. & PRO-FGD-06 \\
\hline IV. & Dimensions: Justice & \\
\hline 15. & The loan procedure in USP/KSP reflects the equality of members. & KEA-FGD-01 \\
\hline 16. & The same interest rate policy for members' voluntary deposits & KEA-FGD-02 \\
\hline 17. & Notification of RAT implementation is conveyed to all members. & KEA-FGD-03 \\
\hline 18. & $\begin{array}{l}\text { Distribution of reports from management and supervisors evenly to members who } \\
\text { are present or not present at the RAT. }\end{array}$ & KEA-FGD-04 \\
\hline 19. & $\begin{array}{l}\text { Management staff who excel must be given an award calculated from the length of } \\
\text { work, services and performance in improving the welfare of members. Meanwhile, } \\
\text { managers who perform poorly are penalized. }\end{array}$ & KEA-FGD-05 \\
\hline V. & Dimensions: Accountability & \\
\hline V.a. & Organizational and Management Accountability Indicators & \\
\hline
\end{tabular}




\begin{tabular}{|c|c|c|}
\hline 20. & Legality of Legal Entities: Notary Deed of Establishment and SK Endorsement. & AKU-04-01 \\
\hline 21. & $\begin{array}{l}\text { Legality of Legal Entity: Have a Certificate of Cooperative Identification Number } \\
\text { (NIK). }\end{array}$ & AKU-04-02 \\
\hline 22. & $\begin{array}{l}\text { Increasing member participation in capital accumulation (in the form of mandatory } \\
\text { savings). }\end{array}$ & AKU-04-03 \\
\hline 23. & Increased member transactions with cooperatives. & AKU-04-04 \\
\hline 24. & There are job descriptions and job specifications & AKU-04-05 \\
\hline 25. & $\begin{array}{l}\text { There is a good organizational structure, there are no double positions and vacant } \\
\text { positions. }\end{array}$ & AKU-04-06 \\
\hline 26. & Cooperative Institutional Standard Operating Procedure (SOP) is available. & AKU-04-07 \\
\hline 27. & Cooperative Management Operations Standard (SOM) available & AKU-04-08 \\
\hline 28. & $\begin{array}{l}\text { Implementation of the Annual Member Meeting (RAT) on a regular and timely basis } \\
\text { and in accordance with applicable laws and regulations }\end{array}$ & AKU-04-09 \\
\hline 29. & RAT decision notarized & AKU-04-10 \\
\hline 30. & the existence of cooperative training for administrators and supervisors & AKU-04-11 \\
\hline 31. & There is a competency-based assessment that is tested for employees/management. & AKU-04-12 \\
\hline 32. & Formal education programs are available for administrators and management. & AKU-04-13 \\
\hline 33. & Increase in the number of members in the past year & AKU-04-14 \\
\hline 34. & Decrease in the number of members leaving in the past year. & AKU-04-15 \\
\hline 35. & $\begin{array}{l}\text { Awards received by cooperatives in the last } 3 \text { years, both from within and from } \\
\text { outside the Department of Cooperatives and SMEs. }\end{array}$ & AKU-04-16 \\
\hline V.b. & Cooperative Business Accountability Indicators & \\
\hline 36. & The suitability of the cooperative's business license with business activities. & AKU-04-17 \\
\hline 37. & $\begin{array}{l}\text { Business engagement between members/the existence of transactions between } \\
\text { members. }\end{array}$ & AKU-04-18 \\
\hline 38. & $\begin{array}{l}\text { The relationship between the cooperative's business and the member's business as a } \\
\text { provider of goods and services or vice versa. }\end{array}$ & AKU-04-19 \\
\hline 39. & Percentage increase in turnover & AKU-04-20 \\
\hline 40. & Profit percentage increased compared to the previous year. & AKU-04-21 \\
\hline 41. & The cooperative has a written work plan for a minimum of 3 years. & AKU-06-22 \\
\hline 42 & $\begin{array}{l}\text { Cooperatives have a work plan of at least } 1 \text { year as a guide for short-term } \\
\text { cooperative operational activities. }\end{array}$ & AKU-06-23 \\
\hline 43. & $\begin{array}{l}\text { The vision, mission, goals and work plans are known and understood by the } \\
\text { management, supervisors, managers and all employees (by cross-checking). }\end{array}$ & AKU-06-24 \\
\hline 44. & $\begin{array}{l}\text { Operational decision making is carried out by the manager independently } \\
\text { (confirmation to management and supervisors). }\end{array}$ & AKU-06-25 \\
\hline V.c. & Financial Accountability Indicators & \\
\hline 45. & Own capital ratio is greater than loan capital & AKU-04-26 \\
\hline 46. & Ability to provide funds to meet maturing obligations (Liquidity Level). & AKU-04-27 \\
\hline 47. & $\begin{array}{l}\text { There is an increase in mandatory savings in real terms compared to mandatory } \\
\text { savings. }\end{array}$ & AKU-04-28 \\
\hline 48. & $\begin{array}{l}\text { The ability of cooperatives to fulfill their obligations (solvability): Percentage of } \\
\text { assets with liabilities. }\end{array}$ & AKU-04-29 \\
\hline 49. & Ratio of Net Profit to Assets (Return On Assets). & AKU-04-30 \\
\hline 50. & Percentage of additional assets from the previous year. & AKU-04-31 \\
\hline 51. & $\begin{array}{l}\text { Completeness of presentation of internal financial statements (balance sheet, PHU, } \\
\text { cash flows, changes in equity and notes to financial statements). }\end{array}$ & AKU-04-32 \\
\hline 52. & The cooperative has been audited by KAP & AKU-04-33 \\
\hline 53. & KAP audit results opinion & AKU-04-34 \\
\hline 54. & The ratio between operating income and operating costs. & AKU-04-35 \\
\hline
\end{tabular}




\begin{tabular}{|c|c|c|}
\hline VI. & Dimensions: Institutional & \\
\hline 55. & $\begin{array}{l}\text { The cooperative has a good security system for all important documents (as } \\
\text { evidenced by the existence of a security system for important documents and storage } \\
\text { facilities) }\end{array}$ & KEL-06-01 \\
\hline 56. & $\begin{array}{l}\text { There is a RENSTRA (vision, mission, objectives, program objectives and annual } \\
\text { activities) }\end{array}$ & KEL-04-02 \\
\hline 57. & There is a Cooperative Budget and Revenue and Expenditure Plan (RAPBK). & KEL-04-03 \\
\hline 58. & $\begin{array}{l}\text { Regular evaluation of the Cooperative Revenue and Expenditure Budget Plan } \\
\text { (RAPBK) }\end{array}$ & KEL-04-04 \\
\hline 59. & $\begin{array}{l}\text { Cooperatives cooperate with other parties and/or other cooperatives to improve the } \\
\text { professionalism of cooperatives. }\end{array}$ & KEL-FGD-05 \\
\hline 60. & Cooperatives establish business cooperation with cooperatives / other parties. & KEL-FGD-06 \\
\hline VII. & Dimensions : Capital & \\
\hline 61. & $\begin{array}{l}\text { The growth rate of own capital is equal to or greater than the growth rate of assets } \\
\text { (calculated based on data in the Balance Sheet) }\end{array}$ & PER-06-01 \\
\hline 62. & $\begin{array}{l}\text { The growth rate of own capital originating from members is at least } 10 \% \text { compared } \\
\text { to the previous year (calculated based on data in the Balance Sheet) }\end{array}$ & PER-06-02 \\
\hline 63. & $\begin{array}{l}\text { Provision for reserves from SHU equal to or greater than a quarter of SHU for the } \\
\text { current year Cooperative savings and time deposits increased by at least } 10 \% \text { from } \\
\text { the previous year }\end{array}$ & PER-06-02 \\
\hline 64. & $\begin{array}{l}\text { Investment in fixed assets from inventory and office expansion funding is financed } \\
\text { with own capital (cross-checking with reports on sources and uses of funds) }\end{array}$ & PER-06-04 \\
\hline VIII. & Dimensions: Earning Asset Quality & \\
\hline 65. & $\begin{array}{l}\text { Loans with a current collectability of at least } 90 \% \text { of the loans provided (proven by } \\
\text { the loan repayment report) }\end{array}$ & DKAP-06-01 \\
\hline 66. & $\begin{array}{l}\text { Every loan given is backed by collateral whose value is equal to or greater than the } \\
\text { loan provided, except for unsecured loan facilities. }\end{array}$ & DKAP-06-02 \\
\hline 67. & $\begin{array}{l}\text { The reserve fund for loan write-off is equal to or greater than the annual non- } \\
\text { performing loan (as evidenced by the loan collectibility report and loan write-off } \\
\text { reserve) }\end{array}$ & DKAP-06-03 \\
\hline 68. & $\begin{array}{l}\text { Last year's non-performing loans can be collected at least one third (as evidenced by } \\
\text { the annual non-performing loan collection report) }\end{array}$ & DKAP-06-04 \\
\hline 69. & $\begin{array}{l}\text { KSP/USP Cooperatives implement loan procedures effectively (cross-checking } \\
\text { between the implementation of loan procedures and their SOP including BMPP) }\end{array}$ & DKAP-06-05 \\
\hline 70. & $\begin{array}{l}\text { KSP/USP Cooperatives implement transparent loan procedures and are socialized to } \\
\text { all members. }\end{array}$ & DKAP-06-06 \\
\hline 71. & $\begin{array}{l}\text { In providing KSP/USP loans, the Cooperative makes decisions based on the principle } \\
\text { of prudence (as evidenced by the results of the loan feasibility analysis) }\end{array}$ & DKAP-06-07 \\
\hline 72. & $\begin{array}{l}\text { Decisions on lending and/or placement of funds are made through the committee } \\
\text { (proven by the minutes of the committee meeting) }\end{array}$ & DKAP-06-08 \\
\hline 73. & $\begin{array}{l}\text { KSP/USP Cooperatives review, assess and bind their collateral (proven by binding } \\
\text { documents and/or submission of collateral)/assessment of ceiling limits }\end{array}$ & DKAP-06-09 \\
\hline IX. & Dimensions: Liquidity & \\
\hline 74. & $\begin{array}{l}\text { Have a written policy regarding liquidity control (proven by written documents } \\
\text { regarding business planning) }\end{array}$ & LIK-06-01 \\
\hline 75. & $\begin{array}{l}\text { Have effective administrative guidelines to monitor maturing obligations (proven by } \\
\text { the existence of written documents) }\end{array}$ & LIK-06-02 \\
\hline 76. & $\begin{array}{l}\text { Have an adequate management information system for monitoring liquidity (proven } \\
\text { by written documents in the form of a reporting system for collecting deposits and } \\
\text { granting loans) }\end{array}$ & LIK-06-03 \\
\hline & & 1631 \\
\hline
\end{tabular}




\begin{tabular}{|c|c|c|}
\hline $\mathbf{X}$. & Dimensions: Independence and Growth & \\
\hline 77. & The asset profitability ratio has increased in the last 2 (two) years. & KP-FGD-01 \\
\hline 78. & Own capital profitability ratio has increased in the last 2 (two) years. & KP-FGD-02 \\
\hline 79. & $\begin{array}{l}\text { The ratio of Service Operational Independence has increased in the last } 2 \text { (two) } \\
\text { years. }\end{array}$ & KP-FGD-03 \\
\hline XI. & Dimensions: Cooperative Identity & \\
\hline 80. & The gross participation ratio has increased in the last 2 (two) years. & JDK-FGD-01 \\
\hline 81. & Profit ratio (SHU) to principal savings plus mandatory savings & JDK-FGD-02 \\
\hline 82. & $\begin{array}{l}\text { A written statement to become a member of a cooperative based on a voluntary } \\
\text { principle. }\end{array}$ & JDK-FGD-03 \\
\hline XII. & Dimensions: Cooperative Compliance with Regulations Related to Cooperatives & \\
\hline 83. & Cooperative administrators, supervisors and managers have a NPWP & KOP-FGD-01 \\
\hline 84. & $\begin{array}{l}\text { The management has competency certification from the Cooperative Professional } \\
\text { Certification Institute (LSP). }\end{array}$ & KOP-FGD-02 \\
\hline 85. & USP/KSP has a special permit issued by the relevant agency. & KOP-FGD-03 \\
\hline 86. & $\begin{array}{l}\text { Cooperatives report the Agency's Annual Notification Letter (SPT) on time, in the } \\
\text { last } 2 \text { (two) years. }\end{array}$ & KOP-FGD-04 \\
\hline 87. & $\begin{array}{l}\text { The financial statements submitted in the SPT report are financial statements that } \\
\text { have been audited by KAP. }\end{array}$ & KOP-FGD-05 \\
\hline 88. & $\begin{array}{l}\text { Cooperatives orderly calculate, deposit, and report VAT and PPh Article } 21 \text { Period, } \\
\text { as well as other tax obligations. }\end{array}$ & KOP-FGD-06 \\
\hline XIII. & $\begin{array}{l}\text { Dimensions: Cooperative Compliance with Indonesian Financial Accounting } \\
\text { Standards }\end{array}$ & \\
\hline 89. & Cooperative financial reports are guided by SAK ETAP. & PMK-FGD-01 \\
\hline 90. & Preparation of USP financial statements separate from non-USP units. & PMK-FGD-02 \\
\hline 91. & USP and non USP consolidated financial statements. & PMK-FGD-03 \\
\hline 92. & $\begin{array}{l}\text { The preparation of financial statements is based on the Accounting Information } \\
\text { System. }\end{array}$ & PMK-FGD-04 \\
\hline XIV. & Dimensions: Benefits of Cooperatives for Members & \\
\hline 93. & Increase in SHU (Surplus) received per member per year. & MKA-04-01 \\
\hline 94. & $\begin{array}{l}\text { There are members whose businesses are promoted (micro to small or small to } \\
\text { medium). }\end{array}$ & MKA-04-02 \\
\hline 95. & There are goods/services offered at lower prices than competitors. & MKA-04-03 \\
\hline XV. & Dimensions: Benefits of Cooperatives to Society. & \\
\hline 96. & There are cooperative workers from the surrounding environment. & MKM-04-01 \\
\hline 97. & $\begin{array}{l}\text { Cooperative contribution in the form of funding for religious, social, community, } \\
\text { health, education activities in the surrounding environment. }\end{array}$ & MKM-FGD-02 \\
\hline
\end{tabular}

\section{RESULT}

After the stages of compiling the development of a comprehensive Cooperative Governance Implementation Quality Measurement have been completed, the next stage is testing the implementation level on two cooperatives that have already been implemented, namely the BPK RI Employee Cooperative and KSP SMS. The results of the answers to the questionnaire that have been distributed to supervisors, administrators, and cooperative management, obtained a score of $56.7 \%$ (fifty six point seven percent), equivalent to a grade of "not good". This means that BPK RI cooperatives are at the second level from the bottom in implementing cooperative governance principles. There are still relatively few governance indicators applied. Of the 97 indicators tested, only 55 indicators answered "yes" or had been implemented. The rest, 42 indicators received a 'no' answer.In the BPK RI cooperative, there are still many weaknesses that occur, especially in the Savings and Loans Unit. The weaknesses are: (1) There was a downward trend in lending to members. Whereas savings and 
loan units are the main contributors to SHU production; (2) Management is not skilled at offering interest rates for loans that are more competitive than those offered by general banking institutions; (3) Cooperatives have not succeeded in offering voluntary savings to members, as loan disbursement capital; (4) The BPK RI Cooperative does not yet have detailed policies and procedures related to the savings and loan business. For example, standard loan approval procedures and loan repayment procedures before maturity; (5) The management of savings and loans is considered very weak, indicated by the data management still using the manual method. Not yet based on accounting information system. Only using the help of MS.Excel computer operations carried out by one cooperative officer.

Assessment of implementation level of Development of Quality Measurement of Cooperative Governance Implementation in KSP SMS The score obtained by KSP SMS on the level of governance implementation is $84.5 \%$ (Eighty Four point Five Percent), equivalent to a good rating level. This means that KSP SMS is at the second level of implementation from the top level. Cooperatives have practiced good governance but there are still weaknesses in the implementation of governance, although not significant. Of the 97 indicators available to answer, there are 82 indicators that get a 'yes' answer. The remaining 15 indicators got a 'no' answer. To get a more complete picture of the results of the questionnaire answers, the authors conducted in-depth interviews with competent informants at KSP Setia Multi Sarana. Based on structured interviews, in order to discuss the results of the questionnaire, several interesting facts were found. First, for the transparency dimension, all indicators get a 'yes' answer. An interesting indicator in this dimension is the application of digitization. Marked by the application of savings and loan applications that are based on information technology. Members who will apply for loans do not need to come to the cooperative office. Simply fill out the loan application form in the application that is already available. Applications will be processed in no time. This strategy really supports the smooth running of the cooperative's business in serving the needs of its members. For indicators of the availability of information dissemination facilities/media, KSP Setia Multi Sarana uses the website as a means of conveying information.

There is an 'information wall' facility at the cooperative as a forum for disseminating important information for members who accidentally come to the cooperative's office.Content analysis was carried out on the Accountability Report of the Management and Supervisors for the 2019 Financial Year, with the aim of evaluating the implementation level of Cooperative Governance Quality Measurement. In the Accountability Report of the Management and Supervisory Cooperatives of BPK RI, the average total score for measuring the quality of cooperative governance is the highest score for the capital aspect, with a score of 2.10 for quantitative disclosure and an average of 7.00 for qualitative disclosure. This result is in line with the focused and detailed disclosures prepared by the management and supervisors in the accountability report on cooperative capital. Cooperative capital is closely related to the activities of the savings and loan unit. Funds used for lending to members are sourced from the cooperative's internal capital, in the form of mandatory savings and principal savings. To support the need for loan disbursement funds, it is supported by external capital. External working capital is obtained from the collaboration with national banking institutions. The average total value of the aspect of measuring the quality of cooperative governance is the highest cooperative governance aspect of KSP-SMS, which is the transparency aspect, namely the average value of 3.83 for quantitative disclosure and 5.33 for qualitative disclosure. . This result is in line with the principles adopted by KSP-SMS management and supervisors to promote openness in cooperative management. The most detailed aspect of transparency discussed in the management's accountability report is the performance of savings and loan management. Loan disbursement is a crucial aspect that is disclosed, with the reason that business continuity is strongly influenced by the honesty and openness of the management in managing funds.

\section{REFERENCES}

[1] Afrizal. (2014). Qualitative Research Methods. Jakarta: Rajawali Press 
[2] Article 33 of the 1945 Constitution concerning the economy is prepared as a joint effort based on the principle of kinship

[3] Bretos, I., \& Marcuello, C. (2017). Revisiting globalization challenges and opportunities in the development of cooperatives. Annals of Public and Cooperative Economics, 88(1), 47-73.

[4] Budiyono, T \& Susilowati, C.M.I., (2017), Cooperative governance in Salatiga. Legal Matters, vol. 46 No.3 p. 257-266

[5] Central Bureau of Statistics, 2018 'Statistik Indonesia Statistical Year Book Of Indonesia 2018' https://www.bps.go.id/publication/2018/07/03/5a963c1ea9b0fed6497d0845/statistik-indonesia-2018.html

[6] Cooperative Rating Assessment Indicators. This Perdep does not yet fully discuss cooperative governance. www.depkop.go.id

[7] Crowther, D \& Lauesen, L.M. (eds.). (2017). Hanbook of Research Methods in Corporate Social Responsibility. Cheltenham, UK. Northampton, MA, USA: Edward Elgar.

[8] Favalli, R. T., Gori Maia, A., \& da Silveira, J. M. F. J. (2020). Governance and financial efficiency of Brazilian credit unions. RAUSP Management Journal, 55, 355-373.

[9] Great world-class brand https://www.brilio.net/creator/tahu-nggak-6-brand-hebat-ini-rupanya-dalam-co-operationclass-dunia-lho-76c183.html accessed on September 8, 2021

[10] Guidelines for Health Assessment of Savings and Loans Cooperatives and Savings and Loans Units. www.depkop.go.id

[11] Jordi Surroca Miguel A. García-Cestona Lluís Santamaria, (2006),"Corporate Governance and the Mondragon Cooperatives", Management Research: Journal of the Iberoamerican Academy of Management, Vol. 4 Iss 2 pp. $99-112$

[12] Jordi Surroca Miguel A. García-Cestona Lluís Santamaria, (2006),"Corporate Governance and the Mondragon Cooperatives", Management Research: Journal of the Iberoamerican Academy of Management, Vol. 4 Iss 2 pp. $99-112$

[13] Nkuranga, T., \& Wilcox, K. (2013). Cooperative Performance Index, Field Results and Analysis. USAID-Enabling Market Integration through Rural Group Empowerment (EMIRGE). Rwanda: United States Agency for International Development and CHF International.

[14] Nugrahani, F., \& Hum, M. (2014). Qualitative research methods. Solo: Cakra Books.

[15] Regulation of the Deputy for Institutional Affairs of the Ministry of Cooperatives and Small and Medium Enterprises Number 04/Per/Dep.1/III/2018 concerning Cretaria and

[16] Regulation of the Deputy for Supervision of the Ministry of Cooperatives and Small and Medium Enterprises of the Republic of Indonesia Number 06/Per/Dep.6/IV/2016, concerning

[17] Republic of Indonesia, Law Number 25 of 1992 concerning Cooperatives

[18] Sinuraya, R. E. (2012). Dialogue Between the Principles and Values of Cooperatives and Social Capital at the Marsudi Mulyo Credit Cooperative, Putat Patuk Gunung Kidul. JKAP (Journal of Policy and Public Administration), 16(1), 73-88.

[19] Sun, Y., Wang, T., \& Gu, X. (2019). A sustainable development perspective on cooperative culture, knowledge flow, and innovation network governance performance. Sustainability, 11(21), 6126.

[20] Sun, Y., Wang, T., \& Gu, X. (2019). A sustainable development perspective on cooperative culture, knowledge flow, and innovation network governance performance. Sustainability, 11(21), 6126.

[21] Susianto, T. E., \& Suyanto, S. (2014). Empirical Evidence of the Application of Good Cooperative Governance Principles on Cooperative Performance in Sukabumi. Journal of Accounting \& Taxation Research (JRAP), $1(02), 225-237$.

[22] The world's largest cooperative with a quadrillion turnover, 2020 https://akurat.co/5-koperasi-terbesar-di-duniaada-yang-beromzet-rp142-kuadrillion?page $=2$ accessed on September 8, 2021

[23] Tjakrawerdaja, S. (2019, July 16), Indonesian Cooperative Era 4.0, Kompas Daily Print. Thing. 7

[24] Wibowo, M., \& Subagyo, A.(2017). Good Cooperative Governance, Sleman-Yogyakarta: Deepublish

[25] Yasa, K. S. H., Herawati, N. T., Ak, S. E., Sulindawati, N. L. G. E., \& Ak, S. E. (2018). Effect of Business Scale Age Company Accounting Knowledge on the Use of Accounting Information in Small and Medium Enterprises (SMEs) With Environmental Uncertainty as Moderating Variable in Buleleng District. JIMAT (Accounting Student Scientific Journal) Undiksha, 8(2). 